\title{
The Portryal of Christianity in Achebe's Arrow of God: A Postcolonial Perspective
}

\author{
Tatang Iskarna \\ Sanata Dharma University \\ iskarna@usd.ac.id
}

\begin{abstract}
The emergence of postcolonial criticism makes the voice of Africans' colonial experience heard and seriously considered. In some ways, this voice is a little bit different from what the European poets or novelists have expressed in their literary texts. For most Europeans, colonialism is perceived as a civilizing force that benefits and progresses to the colonized African societies, primarily through one of its arms: Christianity. Although this religion, as most missionaries propose, has nothing to do with the worldly affair, such as a lust for natural resources and colony, it becomes an important cultural element to help the Europeans conquer the colonized African natives. During the era of colonialism, Christianity in Western discourse is perceived as a means of setting the African natives free from the barbaric traditional belief and savage way of life. Through Christianity, the colonized African natives are educated and taught to live a more modern and civilized life. However, some African writers at times give a different perspective on Christianity. This article explores how Christianity is portrayed through the characters and conflicts in Arrow of God (1964), a novel written by a Nigerian named Chinua Achebe. This portrayal can lead to a postcolonial discourse the novel intends to propose.
\end{abstract}

\section{Keywords: Christianity, colonialism, postcolonial criticism, postcolonial discourse}

\begin{abstract}
Abstrak
Munculnya kritik sastra poskolonial menjadikan suara yang mengekspresikan pengalaman kolonialisme dapat didengar dan sungguh-sungguh dapat diberi perhatian. Suara ini dalam beberapa hal agak eberbeda dengan apa yang disampaikan oleh novelis dan penyair Eropa dalam karya-karya mereka. Bagi kebanyakan orang Eropa, kolonialisme dipandang sebagai kekuatan pemberadaban yang dapat memberikan keuntungan dan kemajuan bagi masyarakat Afrika yang terjajah, terutama melalui salah satu tangan kanannya, yaitu agama Kristen. Meskipun agama ini tidak terkait dengan urusan nafsu dunia, seperti keinginan untuk menguasai sumber daya alam maupun tanah koloni seperti yang sering dikatakan oleh para misionaris, agama ini menjadi elemen penting untuk membantu kaum kolonial Eropa manaklukkan orang-orang pribumi Afrika. Selama masa kolonial, agama Kristen dalam wacana Barat dipandang sebagai media untuk membebaskan orangorang Afria dari kepercayaan tradisional yang barbar dan cara hidup yang tidak beradab. Melalui agama ini, orang-orang pribumi Afrika dididik dan diajar untuk menghidupi kehidupan yang lebih modern dan beradab. Namun demikian, beberapa sastrawan Afrika memberikan perspektif yang berbeda terhadap agama Kristen. Artikel ini akan mengeksplorasi bagaimana agama Kristen digambarkan melalui tokoh dan konflik dalam novel Arrow of God
\end{abstract}


(1964) karya sastrawan Nigeria, Chinua Achebe. Gambaran ini akan menuntun pembaca pada wacana poskolonial yang dibangun oleh novel ini.

\section{Kata kunci: Agama Kristen, kolonialisme, kritik sastra poskolonial, wacana poskolonial}

\section{A. Introduction}

Experience of colonialism shapes the culture of most societies of Africa. Colonialism affects Africans' social, cultural, religious, economic, and political aspects. Some African writers often share their colonial experience in their literary work. Some of them express critical response against colonialism's discourse benefits the Europeans have built amongst the African societies. They scrutinize the colonial relationship and sets out in one way or another to resist colonialist perspectives. They deconstruct its myth, the race superiority, the imagery of subordination, and power domination (Boehmer, 1995:1).

They also question the salutary effects of empire, such as civilization and conversion, and raise such issues as racism, oppression, orientalism, domination, and exploitation. They offer a counter-narrative to the long tradition of the European imperial narrative. They investigate what happens when two cultures clash and when one of them with its accompanying ideology empowers and deems itself superior to the other. Western values and traditions of thought and literature are guilty of repressive ethnocentrism since the emergence of postcolonial literary criticism (Bressler, 1999:265)

One of the element of European civilizing force which often results in critical response is Christianity. History notes that Christianity and its missions play very significant roles in developing the culture in the colonies in Africa. Europeans' expansion is aimed at three goals. They are gold, glory, and gospel. According to Vincent B. Khapoya (2009:101), European development involves three parties. They are the explorer, the missionary, and the colonial administrators. While the explorers give geographical information of the colonies and the colonial administrators, such as soldiers, officers, and capitalists, conquer and occupy the land and people, the missionary is imposed on making cultural approach.

For some certain African people who have internalized the European values, Christianity's arrival as a new belief can bring benefits as they are taught to lead a more modern and rational life. Health clinics are built, schools are established, churches are founded as the centers of new civilization and progress to better the Africans' lives. The missionaries promote education, health, and rational spiritual life towards the African societies. However, the coming of this new religion is not without a problem in the process of internalization. Even clash of culture often happens when some African people still stick to the old traditional belief and culture, while others adopt it and leave the old tradition behind. On the one hand, 
Christianity brings some progress. On the other hand, it sometimes brings conflict amongst the Africans as its values mostly are in opposition to the traditional belief. This kind of colonial experience is caught and felt by Chinua Achebe, a Nigerian writer who witnesses this cultural clash and expresses it in her novel Arrow of God (1964).

This kind of colonial impact issue still occurs because there is always a tension between the traditional and European culture, and the novel Arrow of God is one of the literary works that can portray this tension. How Christianity is perceived will be explored in how the characters and conflicts in the novel are depicted, how these two literary elements can represent the portrayal of Christianity, and what kind the postcolonial discourse is the novel intends to put forward.

\section{B. Some Related Studies on Postcolonial Discourses in Arrow of God}

The novel Arrow of God (1964) was written by Chinua Achebe, a Nigerian novelist who converted to Christianity and then returned to his traditional belief. $\mathrm{He}$ is one of the African writers who concern with the reality that there must be a cultural clash when his tribe identity, that is, Igbo, will be gradually wiped out when the influence of Christianity intrudes. This cultural interaction and conflict cannot be avoided (Nelson, 1998:18). As postcolonial writers, Achebe is determined to build awareness of the colonial influence and build African self-confidence through his novels. Things Fall Apart (1958), No Longer at Ease (1960), and Man of the People (1966) are the ones in which the tension of colonial impact is explored.

Arrow of God is a novel telling about Igbo people in the early $20^{\text {th }}$ century Nigeria who have to face European culture's influence coming along with the colonialism and their internal tribal conflicts of two tribal regions, Umuaro and Okperi. Nigeria at that time is under British colonial administration. The chief of the tribe, Ezulu, tried to defend Igbo values from the European cultural influence, including resisting the conversion to Christianity and rejecting cooperation with the British colonialists to administer the colony by applying the policy of indirect rule. Meanwhile, the Igbo people from Umuaro and Okperi still quarrel over the land they believe is their ancestor's inheritance. The story of Ezeuly rises as he is finally jailed for the consequences of refusing to submit to the colonialist's planning to occupy the land and Igbo people. Unfortunately, it is the time for Igbo people to harvest their yam, a staple food of Igbo people, and Ezeulu must lead the harvest. As most Igbo people do not have empathy on him while he is put into prison, Ezeulu refuses to pray and show the harvest. The Igbo people are annoyed with Ezeulu's decision and ask the local and British Christian priest to say a prayer and lead the crop so that the yam is not rotten. Besides, Igbo people assume that their gods have left Ezeulu as one of his sons dies. The God of Christians, which the priests preach as God of love and mercy, God full of grace, and God of powerful authority, become the starvation solution. Many Igbo people convert to Christianity. 
Some studies on the postcolonial discourse have been conducted. The negative impact of colonialism is discussed in a dissertation entitled Alternity and Hybridity in Anglophone Postcolonial Literature: Ngugi, Achebe, p'Bitek, and Nwapa (2001) Edward Winston Babatunde Woode. In this research, Woode highlights the cultural change of African societies in the form of the diffusion of two cultures.

Seyed Mohammad Marandi from the University of Tehran and Reyhaneh Sadat Shadpour from Allame Tabatabai University, Tehran have published their research entitled "Christianity as an Ideological Instrument: A Postcolonial Reading of Chinua Achebe's Arrow of God in African Journal of History and Culture Vol. 3(4), pp.48-53, May 2011). Using the theory of Althusser about ideology apparatus to have domination over others, this research describes how Chinua Achebe portrays the arrival of Christianity through the missionary institutes results in local culture crises.

Chris Kwame Awuyah from West Chester University, Pennsylvania, has also conducted research entitled "Chinua Achebe's Arrow of God: Ezeulu's Response to Change" using the biographical theory Slave Narrative proposed by Frederic Douglas and Olaudah Equiano. The finding is that some cultural changes are the consequences of African people's openness to the European culture. This has been published in Journal of College Literature Vol. 19/20 No.3 (1 October 1992-February 1993 pp. 214219).

The previous studies' differences will focus on how Christianity is scrutinized in its worldly and spiritual influence, whether worthy or deprived of the colonized native perspective. This article puts Arrow of God in the frame of postcolonial criticism, meaning to say how this text gives a counter-discourse narrative against the European mind and the critical review of local cultures.

\section{Theoretical Review: Christianity from Postcolonial Perspective}

Generally, Christianity is assumed as the religion which is based on Jesus' teaching and life. Jesus' disciples initially adopt this religion, the Jewish people who have grasped Judaism but believed that Jesus is the coming Messiah who will save the Israelites and all human beings in the world who have nearly fallen in sin since the falling of Adam and Eve into Satan's temptation.

Christianity, as Thiessen (1997) states, bases its teaching and belief on the following principles. The first is the belief in the monotheistic God, the creator of heaven and earth and ruler of the universe (1997:113). The second, the human beings God has created fall into sin through Satan's temptation and must be punished so that they need the grace of salvation (1997:231). This salvation comes through Jesus Christ, the Messiah, on whom the punishment of the human beings' sin imposed on the cross (1997:303). The third, the followers and disciples of Jesus, build their fellowship through the church to maintain the believers and preach the 
gospels to those who have not believed in Jesus (1997:473). The fourth, the Bible, is believed to be God's words and Christian life-principle (1997:65). Fifth, Christians believe that there is life after death and eternal life in heaven for those who believe in Jesus's salvation grace (1997:519).

Christianity is a religion of mission, in a way that its good news of salvation from Jesus Christ must be spread to all human beings in this world. To reach out to the people in every part of this world, Christianity has a unique characteristic that generates evangelism's movement to all people (Peters, 2006:39). Every Christian has to share the good news of the gospels with others as Christians' life should be the same as Christ's life (Schnabel, 1967:451). The Bible declares that Christianity starts from Jerusalem and then spreads to Syria, Turkey, Greece, Italy, and all European lands. Christianity finally reaches Africa, Asia, America, and Australia (Schnabel, 1967:33-110). The evangelism proceeds from time to time, including colonialism from $16^{\text {th }}$ to $20^{\text {th }}$ century.

Converting non-European people from traditional belief to Christianity is an essential element of civilizing the heathen, savage, brutal, and address European people usually give to non-Europeans. This spiritual conversion is considered the civilizing mission (Kohn, 2012: par.2; Khapoya, 2012:106-107), and Christianity is part of the civilizing force in colonialism (Guth, 1981:549). Some of the Christian teachings can be used to maintain the colonialist's domination over the colonized societies. Indoctrination and propaganda about the stigma of the traditional belief as a sinful and barbaric behavior becomes the milestone for the colonialists to employ Christianity as the supporting aspect of colonialism. Upon converting to Christianity, the colonized natives are taught to submit and obey colonial administration rulers. What starts as a new belief is that Christianity becomes the ideology that convinced the colonized natives not to resist the colonialists' domination. In this case, Christianity as a religion promotes political tyranny and oppression (Arnsten, 1997: par 3).

Christianity is not a spiritual system of belief separating from the political agenda of European people. Still, it becomes a part of the European culture, and practice is adopted in the colonial structure. European Christians cannot distinguish between their belief and culture. Jesus is forced to be a white European (Arnsten, 1997: par.3). Christianity is used as a theological reference to justify the polarization between the civilized Europeans and the uncivilized African heathen without any respect for the local and native cultural values (Said, 178:12). As Said states, Orientalism is a secular discourse born from Christianity. It becomes the temporal form of Christianity, in a way that it is a kind of religious binary opposition discourse maintained and reconstructed to keep the domination (Said, 1978:121).

According to Memmi, the myth of religious conversion and social welfare in Christianity propagated by the European colonialists does not concern the reality of colonialized natives' lives. Transformation does not mean that the natives will make progress on cultural assimilation steps. The 
colonial relation is still sustained, and the natives cannot gain a new social status. Christianity is used to preserve the unequal social quality, and racism is a useful device to create such a situation (1965:72-74).

Meanwhile, for some Africans, adopting Christianity means gaining access to colonial society's social and economic chance. Some of them convert not to live its spiritual principles of Christian teaching but to take advantage of its social and economic effect. Christianity is used as a means of becoming part of the European superiority (Berkhof, 2014:367).

All the above propositions of Christianity perceived from postcolonial approach will be the basis of theory used to analyze how Christianity's portrayal is depicted in Achebe's Arrow of God. In this novel, Christianity is experienced by the African natives, especially Igbo people, concerning the tension between two forces: local traditional spiritual values and European cultural discourse.

\section{Discussion}

The characters in Arrow of God generally are classified into four groups. They are the British colonialist, the Igbo natives who adopt Christianity, the Igbo figures who preserve the purity of their traditional culture, and the Igbo people who maintain the conventional Igbo values on the one hand and internalize the European culture on the other hand.

John Goodcountry, Moses Unachukwu, Joshua Hart, James Ikedi, dan Oduche are the characters who adopt Christianity. Even John Goodcountry becomes the local evangelist in the Niger river delta. He is assigned to manage missionary organizations, including the Christian schools, health centers, and churches in Umuaro. Moses Unachukwu is an Igbo man who has converted to Christianity, can speak English and is educated in a Christian school. The tribe spiritual chief, Ezeulu, is the one who keeps the traditional Igbo values. He is the messenger of Ulu, one of the Igbo's gods and Igbo people.

The portrayal of Christianity can be traced from some sequences in the novel. The series that needs to be emphasized is Ezeulu's intention to understand Christianity as the new belief in Umuaro and identify how it affects his people. Then, Oduche's life journey experiences and gains education in the Christian school and missionary institute, the story of converting Igbo people in Niger river, the disrespecting the python, and the calling off the harvest of yam in Umuaro. John Goodcountry, Moses Unachukwu, Ezeulu, and Oduche are the four characters representing Christianity's portrayal. All these characters and conflict lead to an image of Christianity as the religion which conveys the ideology of orientalism and brings cultural destruction on the one hand.

On the other hand, it has a beneficial impact on particular situations and conditions for Igbo people, especially helping to overcome the Igbo's food crisis. This discussion's portrayal is perceived from what the characters say, thought, behave, and act in their relationships or conflicts 
with other characters. It is not what Christianity is but what Christianity looks like through the characters and conflict.

\section{Christianity as the Religion Conveying the Ideology of Orientalism}

Here, the ideology of orientalism refers to what Edward Said proposes in his monumental book Orientalism (1978). It is a kind of binary opposition point of view between the civilized West and the barbaric Africans, believers and heathens, God and Satan, rationality and superstition, and heaven and hell. This polarization is the strategy of the West to have domination over the colonized natives.

Christianity is assumed to produce rational believers who make vast progress in knowledge as they are under Christian school or church teaching principles. They are more logical as they do not accommodate traditional superstition and belief in satanic idols. Christianity is considered more civilized as Christians do not recommend the people to have a primitive lifestyle. Christianity is the true belief as its followers worship true and monotheist God, not unreliable gods represented in idols.

John Goodcountry is a Christian who assumes that his belief is better than the traditional Igbo religion. He is an Igbo man who has left his orthodox faith and converted to Christianity. Even he becomes the local evangelist. Igbo traditional belief is viewed as evil customs from his Christian view as the Igbo natives pray in tombs and worship animals, such as python and iguana. Python is represented as the snake which temps the first human beings, Adam and Eve, into sin. Hence, it is right to kill the snake as proof of the Igbo people's obedience to the Christian faith. Here are the narratives showing the above proposition:

Mr. Goodcountry told the converts of Umuaro about the early Christians of the Niger Delta who fought the bad customs of their people, destroyed shrines, and killed the sacred iguana. He told them of Joshua Hart, his kinsman who suffered martyrdom in Bonny. "If we are Christians, we must be ready to die for the faith," he said. "You must be ready to kill the python as the people of the rivers killed the iguana. You address the python as Father. It is nothing but a snake, the snake that deceived our first mother, Eve. If you are afraid to kill it, do not count yourself a Christian." The first Umuaro man to kill and eat a python was Josiah Madu of Umuagu. But the story did not spread outside the little group of Christians, most of whom refused, however, to follow Joshua's example. They were led by Moses Unachukwu, the first and the most famous convert in Umuaro. (Achebe, 1974:47).

Evangelists in the Christian mission and church do not recommend python's worship as python represent demonic power. Oduche, one of the Ezeulu's sons, must not respect python in his house nor sanctify it as it is a 
sinful behavior and attitude. Oduche, interested in going to a Christian school to gain new knowledge, is willing to do this faithful action. However, Oduche has his way in killing the snake. He does not kill the snake directly, and his killing is not exposed to the public:

At that moment, Oduche took his decision. There were two pythons - a big one and a small one - which lived almost entirely in his mother's hut, on top of the wall which carried the roof. They did no harm and kept the rats away; only once were they suspected of frightening away a hen and swallowing her eggs. Oduche decided that he would hit one of them on the head with a big stick. He would do it so carefully and secretly that when it finally died, people would think it had died of its own accord. (Achebe, 1974:50)

Christianity is contrasted to the Igbo's traditional belief system in the way that Christians worship God, and they are called believers. It is distinguished to the Igbo people who are addressed as heathen as they adore animals, like python and iguana. The word "heathen" is constructed as the discourse to address the people worshipping and sanctifying animals:

The progress of Still Mark's came about in a somewhat unusual way. Mr Goodcountry, with his background of the Niger Delta Pastorate, which could already count native martyrs like Joshua Hart to its credit, was not prepared to compromise with the heathen over such things as sacred animals. Within weeks of his sojourn in Umuaro, he was ready for a little war against the royal python in the same spirit as his people had fought and conquered the sacred iguana. (Achebe, 1974:213).

\section{Christians}

Christianity is also assumed to be the true religion compared to the Igbo traditional belief that still recommends the followers idolize animals and shrines. This is stated by a bishop who supervises the local Christian priests.

He (the bishop) had also replied to Ezidemili's petition assuring him that the catechist would not interfere with the python. At the same time praying that the day would not be far when the priest and all his people would turn away from the worship of snakes and idols to the true religion. (Achebe, 1974:214)

Christianity is depicted as a religion that is more rational than the Igbo traditional belief. When Ezeulu refuses to lead the harvest prayer and ceremony to the god of Ulu to ask for salvation and welfare, Igbo people 
are worried about the starvation resulted from their spiritual leader's attitude. Ezeulu rejects to do so because he takes revenge on his people who do not care for him when he is taken to prison. Ezeulu's prayer is the only way to allow the harvest to start. This situation is taken as a chance to tell the people how irrational the Igbo belief is. How the starvation can happen because of the leader's behavior and advocating people to convert to a new thought system is Christianity. The African irrational belief makes Igbo people suffer from famine. Christian God is more gracious as He is described as the giver of all good things who shows a right way:

Now Mr. Goodcountry saw in the present crisis over the New Yam Feast an opportunity for fruitful intervention. He had planned his church's harvest service for the second Sunday in November, the proceeds from which would go into the fund for building a place of worship more worthy of God and Umuaro. His plan was quite simple. The New Yam Festival was the misguided heathen attempt to show gratitude to God, the giver of all good things. They must be saved from their error, which was now threatening to ruin them. They must be told that whoever made his thank-offering to God could harvest his crops without fear of Ulu (Achebe, 1974:215).

\section{Christianity as the Religion Bringing about Cultural Destruction}

In Arrow of God, Christianity is portrayed as the new spiritual system that destroys the traditional African belief. The converters adopt the traditional norm and values, such as shrine rites, animal worship, and harvest rites gods. The Igbo standards, traditions, and habits are not respected anymore. This disrupts the Igbo people's lives in Umuaro as all social relations and structures are based on this traditional belief. That is why the tribe chief Ezeulu is worried about Christianity's spread, which can wipe out the conventional idea as more Igbo people convert to this new religion. Christianity is described as a leper, contiguous disease that will contaminate all Igbo people and destroy the traditional culture:

But now, Ezeulu was becoming afraid that the new religion was like a leper. Allow him a handshake, and he wants an embrace. Ezeulu had already spoken strongly to his son, who was becoming more strange every day. Perhaps the time had come to bring him out again. But what would happen if, as many oracles prophesied, the white man had come to take over the land and rule? It would be wise to have a man of your family in his band in such a case. As he thought about these things, Oduche came out from the inner compound wearing a white singlet and a towel they had given him in the school. Nwafo came out with him, admiring his singlet. Oduche saluted his father and set out for the mission because it was Sunday 
morning. The bell continued ringing in its sad monotone. (Achebe, 1974:43)

The unstoppable influence of Christianity has a destructive impact on the Igbo culture. The Christians are advised to destroy anything relating to idol worshipping. The local evangelist, John Goodcountry destroys the vanishing of the python in the houses of Igbo people. Igbo people are urged not to sanctify the animals to show their faithfulness to Christianity. Snake is associated with demonic power who tempts Adam and Eve to fall into sin:

"It is not true that the Bible does not ask us to kill the serpent. Did not God tell Adam to crush the serpent which deceived his wife?" Many people clapped for him. "Do you hear that Moses?" (Achebe, 1974:49)

Many shrines are burnt down as these places are considered the source of barbaric rites and intersession between gods and Igbo people. However, some people are angry with this situation:

The bishop had just had a very serious situation in another part of his diocese on this same matter of the python. A young, energetic ordinance had led his people on a shrine-burning adventure and had killed a python in the process, at which point the villagers had chased out all the Christians among them and burnt their houses. (Achebe, 1974:214)

The conversion to Christianity also shakes the social structure of the leadership and power system in Igbo society. The Christian Igbo give more respect to the Christian priests and missionaries than the tribal chief. Igbo people do not admit Ezeulu as their leader. Harvest rites are no more needed as the Igbo people adopt the new system of belief. Instead of praying in shrines and worshipping python and iguana, they gather together and pray with other Christians in a fellowship. They can harvest the yam without the consent of the tribal chief but in the grace of Christian God.

The brotherhood amongst Igbo people in Umuaro is broken. The relation between Igbo people in Umuaro and Okperi is also disturbed as they have different religious systems after Christianity's arrival. Christianity is also considered a religion that gives consent to colonialists' invasion to a remote area as the missionaries will benefit from it, a new site to spread the gospel.

\section{Christianity as the Problem Solver of the Natives' Crisis}

Chinua Achebe in this novel does not seem to be one-sided. He exposes the complexity of the Igbo's perception toward Christianity. Ezeulu, who is depicted as the tribal chief who struggles to stop the Christian 
influence, is presented as the one who does not close himself to this new religion. At times church and school are perceived as the source of new knowledge. He calls it wisdom:

The place where the Christians built their place of worship was not far from Ezeulu's compound. As he sat in his obi thinking of the Festival of the Pumpkin Leaves, he heard their bell: GOME, GOME, GOME, GOME, GOME. His mind turned from the festival to the new religion. He was not sure what to make of it. At first, he had thought that since the white man had come with great power and conquest, some people needed to learn the ways of his deity. That was why he had agreed to send his son, Oduche, to learn the new ritual. He also wanted him to learn the white man's wisdom, for Ezeulu knew what he saw of Wintabota and the stories he heard about his people that the white man was wise. (Achebe, 1974:42)

Even, Ezeulu is the one who sends his sons to a Christian school to learn the new culture and wisdom. The Christian prayer and worship call from the church represent wisdom, good power, and knowledge. Igbo people now believe that there are many things to learn from the missionary and colonialists. Christianity then is associated with excellence after Ezeulu receives the report from the Igbo boys who gain an education in a missionary school and church:

If Oduche had any reluctance left after his father had talked to him, it was removed as soon as he began to go to church. He found that he could learn very quickly, and he began to think of the day when he could speak the language of the white man, just as their teacher, Mr. Molokwu, had spoken with Mr. Holt when he had visited their church. But there was somebody else who had impressed Oduche even more. His name was Blackett, a West Indian missionary. It was said that this man, although black had more knowledge than white men. Oduche thought that if he could get one-tenth of Blackett's experience, he would be a great man in Umuaro. He made excellent progress and was popular with his teacher and members of the church. He was younger than most other converts, being only fifteen or sixteen. This teacher, Mr. Molokwu, expected great things and prepared him for baptism when he was transferred to Okperi. The new teacher was a man from the Niger Delta. He spoke the white man's language as if it was his own. His name was John Goodcountry. (Achebe, 1974:46)

Christianity is depicted as the new religious system that can give solution to the Igbo critical problem, which is the danger of starvation due to the cancellation of the harvest rites. When the yam is not yet harvested, it will soon be rotten and cannot be eaten. Famine will be waiting then. This 
critical problem caused by the tribal chief of Igbo, who is reluctant to hold the rites and say a prayer to their god to consent to the harvest, is seen as a chance for Christians to spread the good news. The taking over of the rites by the Christian priest prevents the Igbo people from being starved:

So the news spread that anyone who did not want to wait and see all his harvest ruined could take his offering to the god of the Christians who claimed to have power to protect such a person from the anger of Ulu. Such a story at other times might have been treated with laughter. But there was no more laughter left in the people. (Achebe, 1974:216)

\section{Postcolonial Discourse in the Novel}

From the perspective of postcolonial criticism, Christianity in Arrow of God is perceived differently from the European discourse. Christianity, which is considered a true religion with its monotheism, might be religion conveying Orientalism's ideology. Its view towards human beings is based on the polarization of the civilized and primitive, God and demonic power, truth and false belief, heaven and hell, and rationality and superstition. This portrayal deconstructs what the European writers propose in their colonial discourse.

The arrival of Christianity is not always described as a civilizing power. It somehow has an aggressive and destructive influence on the traditional and local culture. The social structure is changed, the brotherhood is broken, and the tribal leadership is altered. The dispute of local parties grows as this new religion applies the evangelism system in spreading the belief. These all are the cultural impact of Christianity.

However, this novel urges the reader not to view in black-and-white spectacles. In some ways, Christianity is also beneficial for Igbo people. Missionaries introduce new knowledge and wisdom which are part of Christianity, to the natives. A new perspective on spirituality, health, and progress are presented through Christianity. However, social interaction with a new belief system can give further insight and enlightenment for the natives, although some Christian values are used to justify the domination and oppression toward the colonized natives.

\section{E. Conclusion}

Arrow of God is a novel presenting the portrayal of Christianity from the natives' perspective. However, its primary concern is the impact of colonialism in Nigeria, especially towards the Igbo people. In Western discourse, Christianity is perceived as one of the civilizing forces which can change the primitive society to a more modern and rational social group. Through Christianity, the colonized natives live sensibly, worship true God, and leave behind barbaric traditional rites. 
From the natives' perspective, Christianity is viewed a little bit differently. The natives admit all progress and modernism they gain from the coming of this new religious system. However, practically this religion cannot be separated from the ideology of orientalism, a perspective in viewing things from the binary opposition and polarization of good and evil, civilized and primitive, or rational and superstition. Hence, unequal relation pervades the interaction between Christians and the natives who still hold the traditional belief. This results in horizontal conflict amongst the Igbo people.

This portrayal of Christianity in Arrow of God is expected to enable the readers to view European discourse with an alternative perspective. This critical thought and response to the European speech about Christianity will make the readers realize that the real Christianity might be different from Christianity under colonialism.

\section{Bibliography}

Achebe, Chinua, 1964, Arrow of God, New York: Anchor Books.

Arntsen, Hilde, 1997, The Battle of the Mind: International New Media Elements

of the New Religious Political Right in Zimbabwe, Oslo: University

of Oslo, accessed 11 Agustus 2016 www.postcolonialweb.org

Awuyah, Chris K., 1992, "'Chinua Achebe's Arrow of God: Ezeulu's Response to Change", Journal of College Literature Vol. 19/20 No.3 (1 October 1992February 1993 pp. 214- 219).

Berkhof, H, 2014, Sejarah Gereja, Jakarta: BPK Gunung Mulia.

Bohmer, Elleke, 2005, Colonial and Postcolonial Literature, Oxford: Oxford University Press.

Bressler, Charles E. 1999, Literary Criticism, Upper Saddle River: Prentice Hall

Guth, Hans P., 1981, The Literary Heritage, Toronto: D.C. Heath and Co.

Khapoya, Vincent B., 2013, The African Experience, London: Pearson Education

Kohn, Margaret, 2012, "Colonialism", The Stanford Encyclopedia of Philosophy (Summer Edition), Edward N. Zalta (ed.), accessed 12 Agustus http://plato.stanford.edu/archives/sum2012/entries/colonialism/>.

Memmi, Albert, 1965, The Colonizer and The Colonized, Boston: Beacon Press.

Peters, George W. 2006, Teologi Alkitabiah tentang Pekabaran Injil, Malang: Gandum Mas

Said, Edward, 1978, Orientalism, New York, Vintage.

Schnabel, Eckhard J., 2008, Rasul Paulus Sang Misionaris: Perjalanan, Strategi, dan Metode Misi Paulus, Yogyakarta: Penerbit Andi 
Marandi, Seyed Mohammad and Reyhaneh Sadat Shadpour, 2011, "Christianity As an Ideological Instrument: A Postcolonial Reading of Chinua Achebe's Arrow of God", in African Journal of History and Culture Vol. 3(4), hlm.48-53, Mei.

Thiessen, Henry C., 1997, Teologi Sistematika, Malang: Gandum Mas Woode, Edward Winston Babatunde, 2001, Alterity and Hybridity in Anglophone Postcolonial Literature: Ngugi, Achebe, p'Bitek, and Nwapa, Dissertation, Oklahoma: Oklahoma State University, accesed 14 Mei 2015 , https://shareok.org/handle/11244/331?show=full 